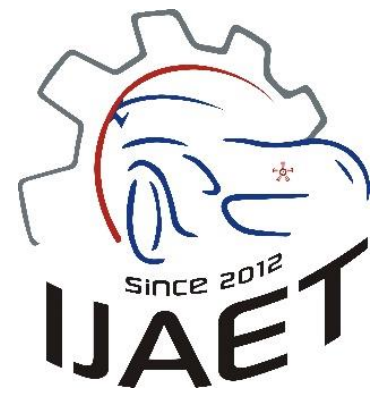

e-ISSN: 2146 - 9067

International Journal of Automotive

Engineering and Technologies

journal homepage:

https://dergipark.org.tr/en/pub/ijaet

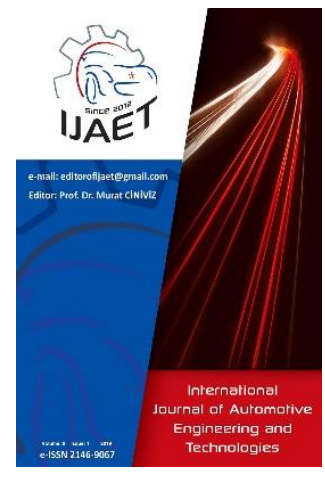

Original Research Article

\title{
Stress and deformation analysis of a connecting rod by using ANSYS

\author{
Mehmet Bulut ${ }^{1}$, Ömer Cihan ${ }^{2, *}$ \\ 1,2* Department of mechanical engineering, Hakkari University, Hakkari, Turkey
}

\section{ARTICLE INFO}

1 0000-0002-0705-6555

2 0000-0001-8103-3063

* Corresponding author omercihan@hakkari.edu.tr

Received: Jan 27, 2020

Accepted: Agu 29, 2020

Published by Editorial Board Members of IJAET

Oral presentation of this article was made at the 4th International Conference on Material Science and Technology in Kizılcahamam / ANKARA (IMSTEC 2019).

(C) This article is distributed by Turk Journal Park System under the CC 4.0 terms and conditions.

\begin{abstract}
The connecting rod is the intermediate component between the piston and the crankshaft, and its primary function is to move the up and down from the piston pin to the crankshaft converting the reciprocating motion into rotary motion of the piston and crankshaft.

This study describes a numerical analysis of connecting rod for determining the critical stress regions. During the analysis of connecting rod, loads corresponding to different engine speeds were assumed to be statically applied, and their corresponding stress and deformation values were evaluated. The power and torque values of engine were utilized to be used as the load boundary conditions in static simulation model, other parameters those of used as input values were geometric dimensions of connecting rod and its material properties.

Numerical analyses were performed for the connecting rod made of SS 304 material. A 3D CAD model was developed for the connecting rod through the SOLIDWORKS software, then drawn solid model was transferred to the ANSYS software with Workbench module. Von mises stress and deformation analyses were evaluated under the different engine speeds with indicating that connecting rod did not failure and fractured under the applied external loads.
\end{abstract}

Keywords: Connecting rod; Modeling; ANSYS; Stress; Deformation.

\section{Introduction}

The connecting rod, which is a dynamic part of the engine, converts the axial motion of the piston to the rotating motion of the crank, so it is an important part for the structural durability and efficiency in the engine. The connecting rods are used in many types of engines ( $\mathrm{V}$ engine, flat engine, radial engine, etc.) [1]. Main parts in the connecting rod was illustrated as shown in the Figure 1. Connecting rod also transfers lubrication oil from the crank end to the piston pin with providing a splash or jet of oil to piston the assembly. For a designing of a connecting rod, different types of materials can be used with different production ways. During the service, critical stresses occur as a combination of axial and bending loading The axial stresses occurred due to the cylinder gas pressure (compressive only) and the inertia force arising in account (reciprocating action (both tensile alongside compressive), whereas bending stresses were caused owing to the virtue of the centrifugal effects [2].

Connecting rods are generally produced from powder forging, forging, and casting methods, and they are exposed to different loads within 


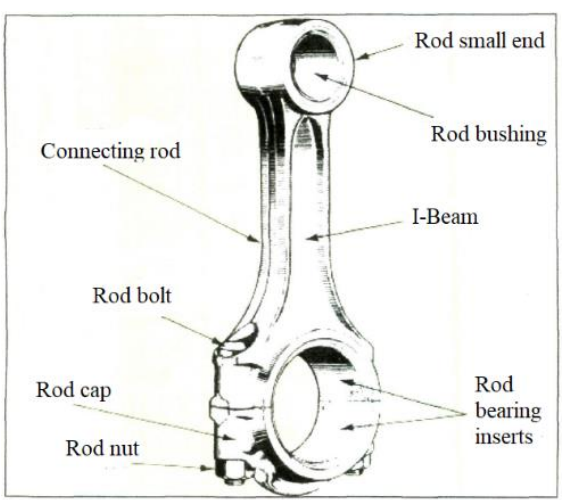

Figure 1: Indication of connecting rod parts [3].

the engine. They are longitudinal compression loading due to the gas pressure in the combustion chamber, mutual pull and compression forces due to changes in the speed of the piston, bending in the body due to release movement and twisting loading exposed due to compression forces [4]. It is known that the connecting rod speeds varies as approximately 2000-3000 rpm during normal operation of the engine. This part, which is subjected to repeated loads at millions of times, must be sufficiently resist to the stresses occurred in the part during the engine movement [5]. In today's technology, it is used as the one of the most widely used component in the internal combustion engines. Researchers performed many studies on the connecting rod incorporating different boundary conditions. Kumar et al. [6] used aluminum reinforced with boron carbide and aluminum 360 materials to analyze critical stress regions of connecting rod. Finite element analyses were performed with help of ANSYS software. In the study conducted by Gautam and Ajit [7], static stress analyses were performed using the finite element methods for the connecting rod made of SS 304 material of NTA 885 BC engine. In the numerical analyses, ANSYS with workbench software was used for static structural analyses by fixing the smaller end while applying the load at bigger end of connecting rod. Stress for analyses were performed for four different parts with indicating that maximum stress points of the part causing to failure are determined by using these numerical analyses. It was also found that most critical region in terms of stresses in the connecting rod was occurred in the region close to the piston side. In another study, it was aimed to reduce the weight of a connecting rod utilizing the forged steel material. A detailed load analysis was carried out in the analysis considering Von mises stress analysis and weight optimization under static loading by using ANSYS/Workbench 9.0 software [8]. Vegi and Vegi [9] conducted discussed the design and analysis of the connecting rod made of carbon steel by using ANSYS 13.0 software. It was found that forged steel compared to other material showed higher safety factor, lighter, and stiffer with less stress values. In the study by Bansal [10] conducted the study on the stress analysis of the connecting rod for stress analyses, and an optimization study was performed under dynamic loading to evaluate maximum stress region, maximum deformation and critical regions. In another study [11], the stress concentration area of the connecting rod was theoretically determined by using a developed formula for the critical regions. Londhe et al. [12] conducted an analysis for the fatigue life of the connecting rod. In the analyses, critical stress points were determined with confirming with experimental data. In addition, stress changes along the cycles were evaluated under different load conditions of the connecting rod. Researchers [13] proposed two different models under different conditions with concluding that they were found to be consistent with one another. In another study [14], the stress distribution and deformations along the connecting rod was analyzed by using mathematical model under different load conditions. Qinghui et al. [15], a diesel engine of connecting rod was analyzed using the ADAMS model, and maximum and minimum stress regions in the connecting rod were identified. Andoko and Saputro [16] conducted that structural steel, aluminum alloy and titanium alloy were designed with Autodesk Inventor and modelled using ANSYS. Stress and deformation tests were performed. As a result, the connecting rod made of structural steel had the highest maximum stress of 82.791 $\mathrm{MPa}$, and aluminium alloy had the highest maximum deformation of $0.84071 \mathrm{~mm}$. Savanoor et al. [17] showed that comparing the von mises stress and total deformation of 2 different aluminium alloys with the forged steel. Von mises stress and total deformation results were close to each other for connecting rod materials. Vinayakrao and Swami [18] worked analysis and optimization of connecting rod used in heavy commercial vehicles. Steel 4340, 
42CrMo4, Al 7075-T7 were used as connecting rod material. The lowest stress was achieved in the Steel 4340 material and the lowest deformation in the $42 \mathrm{CrMo} 4$ material. In another study [19] was designed in CATIA program using aluminum alloy, titanium alloy and beryllium alloy as connecting rod material. It modeled in Ansys program. As a result, maximum von mises stress and maximum deformation were minimum in connecting rod of Beryllium alloy. Suherman et al. [20] worked modeling and static analysis of a connecting rod in range extender engine. In Ansys software was investigated the stress and deformation of the connecting rod as a result of the pressure that occurs during combustion. The maximum value of stress and deformation consist of the connection between the rod connecting rod big end. Hussin et al. [21] studied design and analysis of connecting rod by using aluminium alloy 7068 T6, T6511 material. According to the results obtained, aluminium alloy had more factor of safety, reduce the weight, reduce the stress and stiffer than other material like forged steel.

With the increasing need to have faster product development and yet achieve the optimum design, importance and necessity of the Finite Element Methods (FEA) methods have been increasing. Prediction of accurate stress and deformation notably provides a simple procedure for analyzing and virtual validation of connecting rod. In light of previous studies, the connecting rod was analyzed using an ANSYS R.15 Workbench software. Different forces corresponding to different engine speeds were applied to the connecting rod as well as full load. SS 304 material was selected as connecting rod material due to wide range of application in automotive industry. Under these conditions, von-mises stress and deformation analyses of connecting rod were investigated numerically. Critical stress regions and deformations were mapped over the connecting rod.

\section{Materials and Methods}

\subsection{Numerical Study}

In the study, connecting rod belonging to the four-cylinder engine was drawn in the SOLIDWORKS software (Figure 2). Then, the connecting rod model was transferred to the ANSYS R.15 Workbench software for numerical analyses. Finite element analyses (FEA) were performed for different engine speeds, and material properties of connecting rod were presented in Table 1.

In numerical analyses, number of nodes and elements was 51803 and 25447, respectively. Tetrahedron element type was used. Figure 3 shows mesh shape of the modelled connecting rod. A mesh convergence has been performed for accuracy of results.

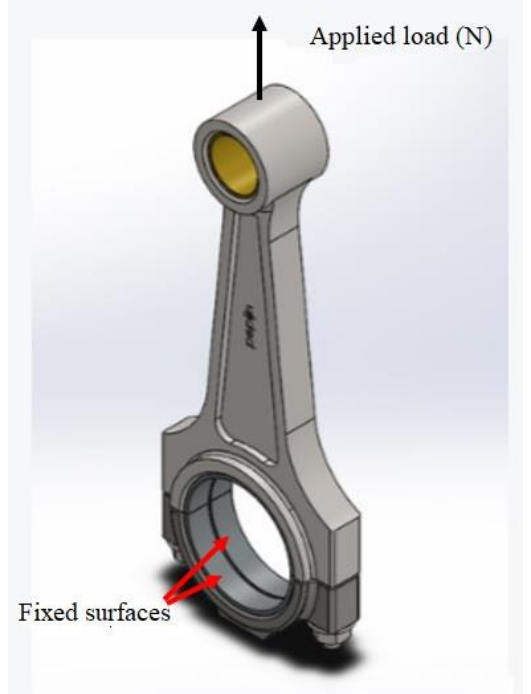

Figure 2. Solid model for connecting rod

Table 1. Connecting rod material properties used in analysis.

\begin{tabular}{ll}
\hline Term & Value \\
\hline Density $\left(\mathrm{kg} / \mathrm{m}^{3}\right)$ & 8030 \\
Poisson's Ratio & 0.3 \\
Young's Modulus $(\mathrm{Pa})$ & $1.93 \mathrm{E}+11$ \\
Bulk Modulus $(\mathrm{Pa})$ & $1.6083 \mathrm{E}+11$ \\
Shear Modulus $(\mathrm{Pa})$ & $7.4231 \mathrm{E}+10$ \\
Tensile Yield Strength $(\mathrm{Pa})$ & $2.15 \mathrm{E}+08$ \\
Compressive Yield Strength $(\mathrm{Pa})$ & $2.1 \mathrm{E}+08$ \\
Tensile Ultimate Strength $(\mathrm{Pa})$ & $5.05 \mathrm{E}+08$ \\
\hline
\end{tabular}

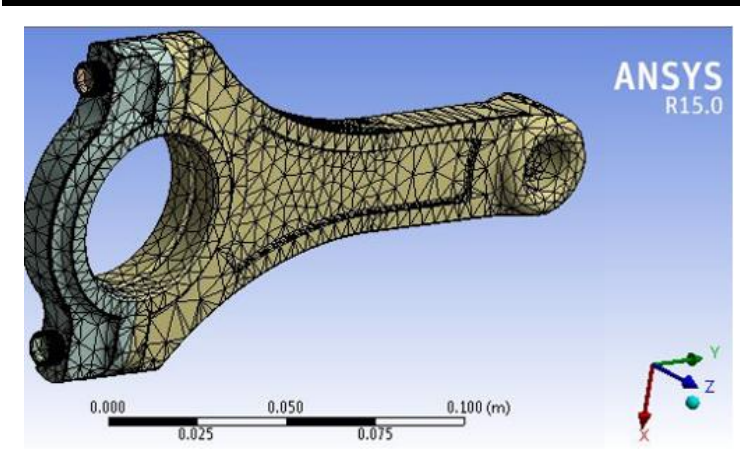

Figure 3. Analysis for connecting rod.

In this study, forces acting on the connecting rod at different engine speeds and full load for each engine speed were calculated as the engine operating conditions. These forces were selected as the crankshaft angle at which the maximum 
pressure was obtained in the combustion chamber. The gas force acting on the connecting $\operatorname{rod}\left(\mathrm{F}_{\mathrm{cr}}\right)$ is calculated as given Eq. 1

$F_{c r}=\frac{\pi D^{2}}{4} P_{S}$

Where, $F_{c r}$ is force on the connecting $\operatorname{rod}(\mathrm{N}), \mathrm{D}$ is bore $(\mathrm{mm})$, Ps is maximum pressure incylinder (MPa). In this way, the gas force is generated after combustion is found.

The force calculation was made while the piston was at the top dead center (TDC). These situation results were presented in Table 2 . Obtained all of these forces were used for the static stress analysis.

Table 2. Obtaining loads at different speeds

\begin{tabular}{lcc}
\hline Engine type & Renault engine 1.6 130 BG \\
\hline Power $(\mathrm{kW})$ & Engine speed (rpm) & Load $(\mathrm{N})$ \\
\hline 13.55 & 1000 & 1017.555 \\
66.22 & 2000 & 2486.439 \\
90 & 3000 & 2252.89 \\
96.05 & 4000 & 1803.251 \\
82.55 & 5000 & 1239.84 \\
\hline
\end{tabular}

While performing static structural analysis with ANSYS, the following formula [2] was used in Eq. 2.

$F=K * X$

Here; $\mathrm{F}$ is load matrix, $\mathrm{K}$ is stiffness Matrix and $\mathrm{X}$ is displacement matrix.

Eq. 1 is called the force balance equation for the linear system. If the element of matrix $[\mathrm{K}]$ is a function of $\{x\}$, the system is known as a nonlinear system. Nonlinear systems include high deformation, plasticity and creep.

\section{Results and Discussions}

The connecting rod of a Renault 1.6 130BG engine was designed with SOLIDWORKS software. Afterwards, this design was carried out using ANSYS R.15 Workbench module and static analyzes were made by FEA. In this context, it was aimed to modelling of the connecting rod, and to evaluate the stresses and deformations at full load depending on different engine speeds. The results of FEA were given in Table 3. From the results at the distribution of stress in different areas in the connecting rod, the stress values on the crankshaft side were less than the piston pin side; this value showed an increasing trend as approaching to the piston pin side. It is observed that the most critical stress area of stress is around the piston pin side, at which force is applied.
The deformation against the force is similarly increased as approaching from the crank side to the piston pin side. Stress and deformation values of the connecting rod depending on engine speed comparatively were shown in Figure 4 . When the results were compared, it was seen that the stress and deformation values were maximum when the engine speed was $2000 \mathrm{rpm}$, revealing the without failure and plastic deformation in the connecting rod. In this case, it can be concluded that the selected material can be used safely in terms of the type of engine used. In addition, it can be concluded that the connecting rod is suitable for operation in the 1000-2000 rpm range at long-term and safe operation. Despite the decrease in the stress values at high speeds, the increase in the loading-unloading amount depending on the unit time may cause the fatigue in the connecting rod with reducing its life.

When change in the deformations were compared in the connecting rod, the occurring maximum the von mises stress value did not cause any damage remaining it's the elastic region. Maximum deformation was naturally occurred at $2000 \mathrm{rpm}$ engine speed corresponding to maximum force value.
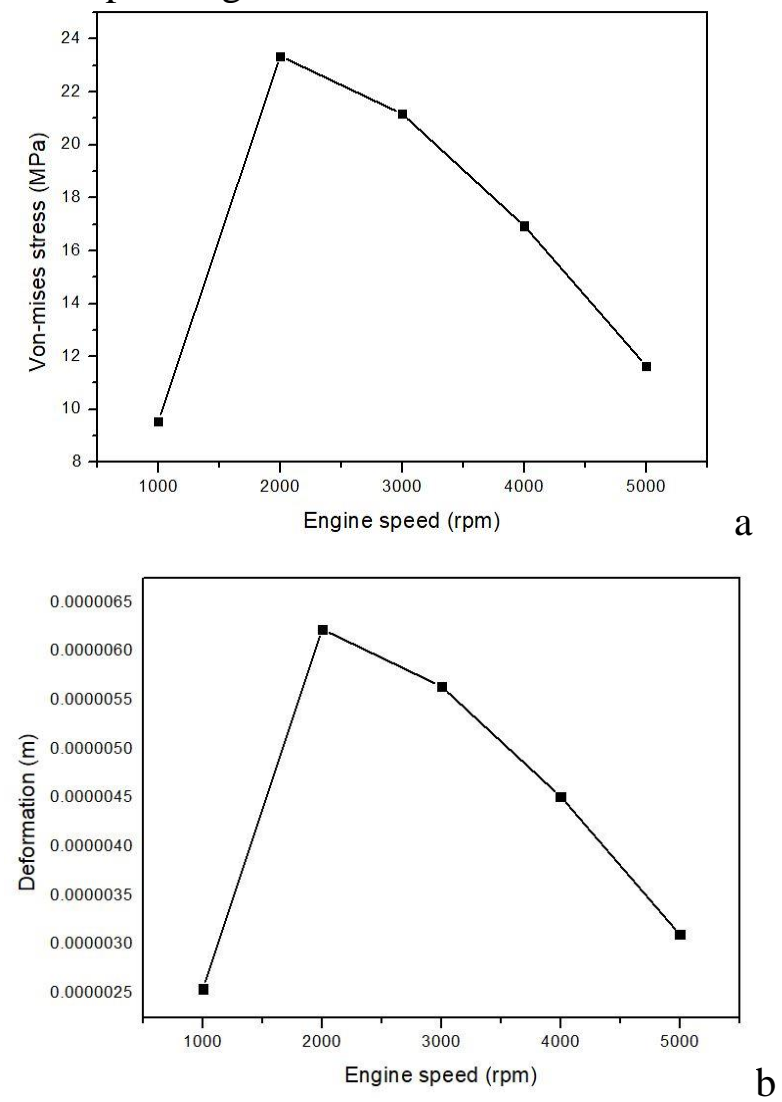

Figure 4. FEA results at different speeds. (a) Von-mises stress, (b) Deformation. 
Table 3. Stresses and deformations at different speeds

\begin{tabular}{|c|c|c|}
\hline $\begin{array}{c}\mathrm{n} \\
(\mathrm{rpm})\end{array}$ & Von-mises Stress (MPa) & Deformation (m) \\
\hline 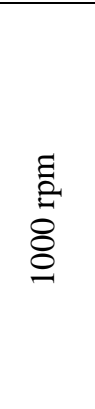 & 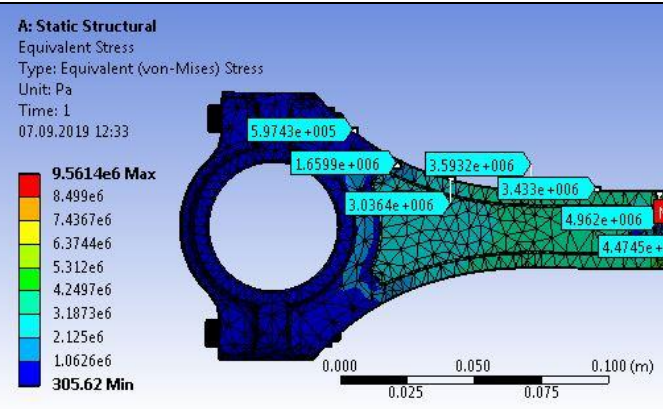 & 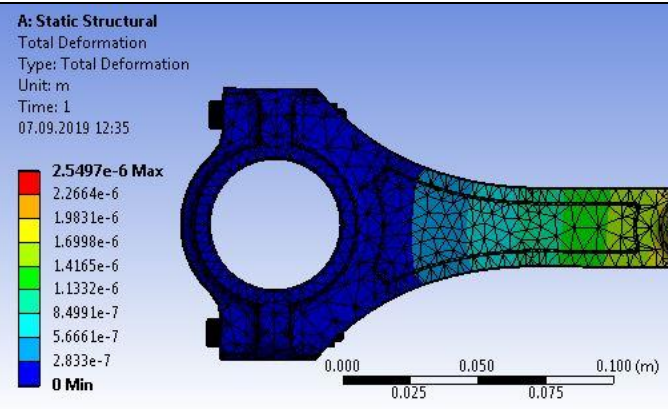 \\
\hline $\begin{array}{l}\text { 름 } \\
\stackrel{0}{8} \\
\stackrel{8}{8}\end{array}$ & 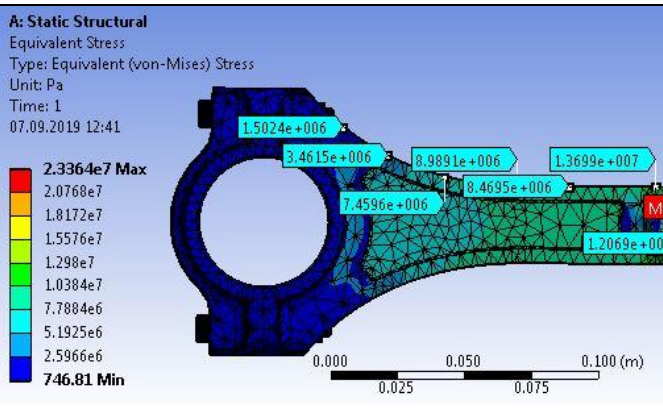 & 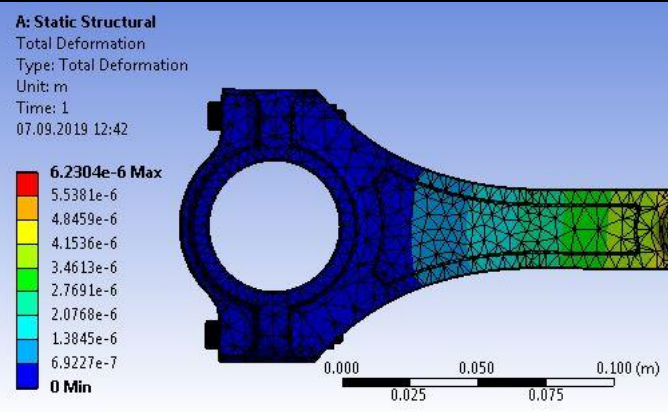 \\
\hline 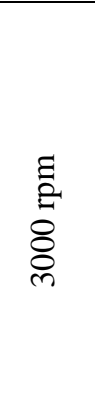 & 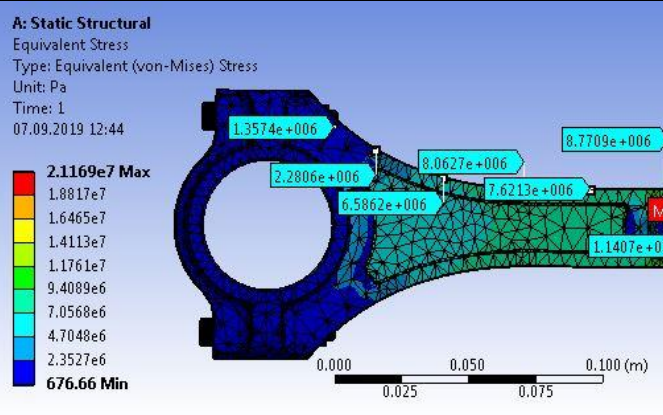 & 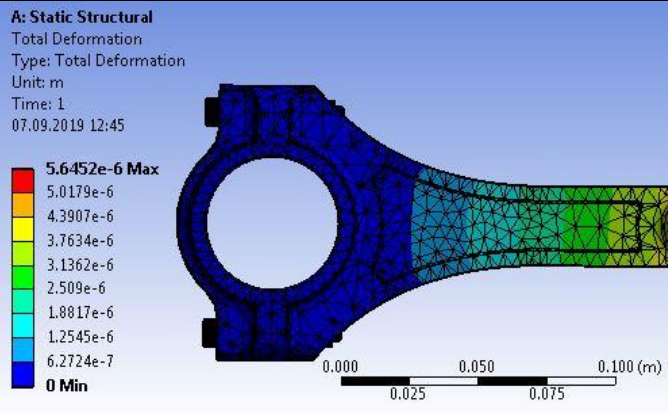 \\
\hline $\begin{array}{l}\text { 믐 } \\
\stackrel{0}{8} \\
\stackrel{8}{8}\end{array}$ & $\begin{array}{l}\text { A: Statit Structural } \\
\text { Equivalent Stress } \\
\text { Type: Equivalent (von-Mises) Stress } \\
\text { Unitit } P \text { a } \\
\text { Time: } 1 \\
07.09 .2019 \\
\text { 12:47 }\end{array}$ & 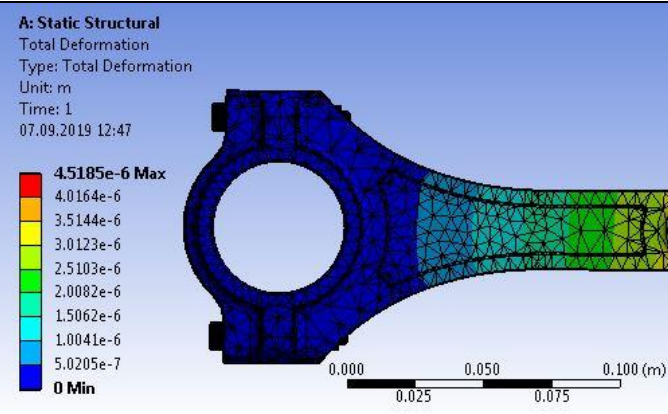 \\
\hline 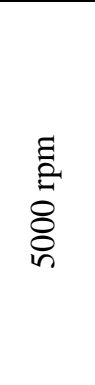 & 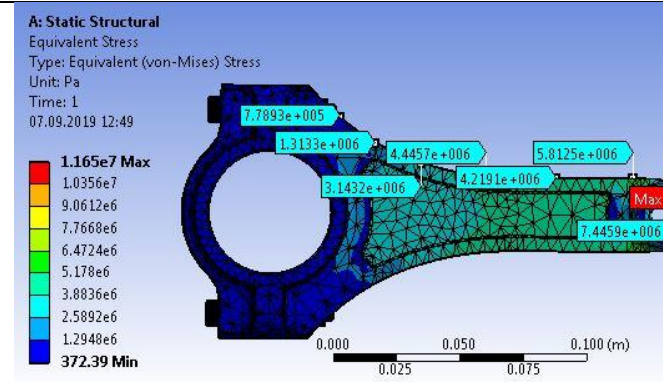 & 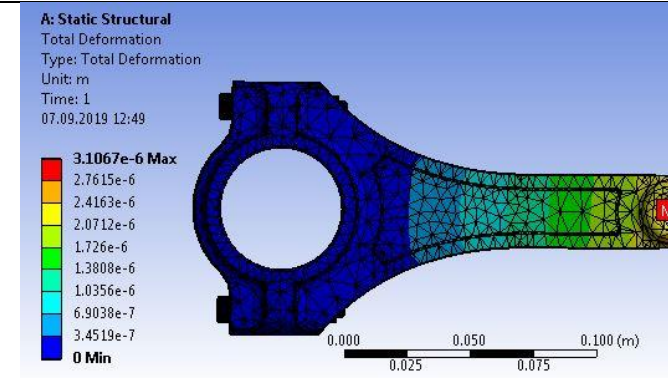 \\
\hline
\end{tabular}

\section{Conclusion}

In this study, by taking into consideration dimensions in the connecting rod belong to
Renault 1.6 130 BG engine, a connecting rod was designed in SOLIDWORKS software. Afterwards, this 3D modelled design was 
transferred to ANSYS R.15 Workbench module for static analyzes. In the engine, forces are obtained at different speeds depending on the power at full load. Variations of static stress and deformation were investigated in the connecting rod. Looking at the distribution of stress in different areas in the connecting rod, the stress values on the crankshaft side were less than the piston pin side; this value showed an enhancement as approaching to the piston pin side. It is observed that the most of critical stress area is found around the piston pin side, which is the part where the force is applied. When the results were compared, it was seen that the stresses and deformations were maximum at $2000 \mathrm{rpm}$. The deformation against the force is similarly increased as approaching from the crank side to the piston pin side.

\section{References}

1. Ozdemir, T. Motor biyel kolunun baş kısmının kırılmasının sonlu elemanlar yöntemi ile nümerik analizi üzerine bir çalışma, Balikesir University, Institute of Science and Technology, Doctoral thesis, Balikesir, Turkey, 2013.

2. Patel, R. K. Finite element analysis of connecting rod using CAE tools, National Institute of Technology, Master's thesis, Haryana, India, 2014.

3. Singh, P.; Pramanik, D.; Singh, R. V. Fatigue and structural analysis of connecting rod's material due to (C.I) using FEA, International Journal of Automotive Engineering and Technologies, 4, 4, 245-253, 2015.

4. Aksoy, Z.; Ozdemir, Z; Ozdemir, T. Kırılarak iki parçaya ayrılabilen biyel kollarının ayrılma parametreleri üzerine bir inceleme, Sakarya University Journal of Science, 16, 2, 113-122, 2012.

5. Acar, H. Biyel kolu analizi, optimizasyonu ve yorulma davranışının incelenmesi, Bursa Technical University, Institute of Science and Technology, Master's thesis, Bursa, Turkey, 2016.

6. Kumar, K. S.; Reddy, K. T.; Hussain, S. A. Modeling and analysis of two wheeler connecting rod, International Journal of Modern Engineering Research (IJMER), 2, 5, 33673371, 2012.

7. Gautam, A.; Ajit, K. P. Static stress analysis of connecting rod using finite element approach, Journal of Mechanical and Civil Engineering (IOSR-JMCE), 10, 1, 47-51, 2013. 8. Charkha, P. G.; Jaju, S. B. Analysis \& Optimization of connecting rod, Second International Conference on Emerging Trends in Engineering and Technology (ICETET-09), Australia, 2009.

9. Vegi, L. K.; Vegi, V. G. Design and analysis of connecting rod using forged steel, International Journal of Scientific \& Engineering Research, 4, 6, 1-10, 2013.

10. Bansal, R. Dynamic simulation of a connecting rod made of aluminium alloy using finite element analysis approach, Journal of Mechanical and Civil Engineering (IOSRJMCE), 5, 2, 1-5, 2013.

11. Francavilla, A; Ramakrishnan, C. V.; Zienkiewicz, O. C. Optimization of shape to minimize stress concentration, Journal of Strain Analysis, 10, 2, 63-70, 1975.

12. Londhe, A.; Yadav, V.; Sen, A. Finite element analysis of connecting rod and correlation with test, SAE paper, 2009-01-0816, 2009.

13. Shenoy, P. S.; Fatemi, A. Dynamic analysis of loads and stresses in connecting rods, Proceedings of the Instituon of Mechanical Engineers, Part C: Journal of Mechanical Engineering Science, 220, 5, 615-624, 2006.

14. Webster, W. D.; Coffell, R.; Alfaro, D. A three dimensional finite element analysis of a high speed diesel engine connecting rod, SAE paper, 831322, 1983.

15. Qinghui, Z.; Yunying, W.; Wei, J. The finite element analysis of connecting rod of diesel engine, International Conference on Measuring Technology and Mechatronics Automation, China, 2010.

16. Andoko, Saputro, N. E. Strength analysis of connecting rods with pistons using finite element method, MATEC Web of Conferences, 204, 1-6, 2018.

17. Savanoor, R. A.; Patil, A.; Patil, R.; Rodagi, A. Finite element analysis of IC engine connecting rod by ANSYS, International Journal of Mechanical Engineering and Robotics Research (IJMERR), 3, 3, 510-516, 2014.

18. Vinayakrao, B. A.; Swami, M. C. Analysis and optimization of connecting rod used in heavy commercial vehicles, International Journal of Engineering 
Development and Research, 5, 3, 659-683, 2017.

19. Nighot, A.; Kulkarni, N.; Khedekar, Y.; Chakre, S.; Singh, S. K. Performance analysis of connecting rod for different materials using FEM, International Journal of Advance Research in Science and Engineering, 7, 4, 95100, 2018.

20. Suherman.; Wahono, B.; Praptijanto, A.; Santoso, W. B.; Nur, A. Modeling and static analysis of a connecting rod in range extender engine, International Conference on Sustainable Energy Engineering and Application (ICSEEA), Indonesia, 2016.

21. Hussin, M. A.; Sinha, P. K.; Darbari, A. S. Design and analysis of connecting rod using aluminium alloy 7068 T6, T6511, International Journal of Mechanical Engineering and Technology (IJMET), 5, 10, 57-69, 2014. 